\title{
INDUSTRIAL STOCKS AS INVESTMENTS
}

\author{
By EDGar J. Meyer, \\ Of Eugene Meyer, Jr., \& Co., New York City.
}

Industrial stocks are constantly becoming of greater importance in the investment field. The term "industrial stocks" is here taken to mean the securities of those corporations engaged primarily in the manufacturing business, as distinguished from public utility, irrigation or mining companies, which are frequently classed under the general term "industrials." The strongest reason for expecting the popularity of these stocks to increase steadily lies in the character of the country's development. We are living to-day in the manufacturing or industrial era, whereas the previous period, which began before $I 880$ and lasted until after $I 890$, was primarily the railroad age. The railroads will always share largely in the normal growth of the country, and while this is still rapid, the day of really great opportunities in the railroad world in this country has gone by. We shall never again witness the transformation in a decade or less of a road, described as a streak of rust, earning nothing and serving a practically uninhabited country, into a modern system, with rockballasted roadbed, protected by block signals and equipped with the very best and latest facilities, and paying handsome dividends.

The earning power of industrial companies is comparatively much more flexible than that of railroads. The tendency to fix by legislation the maximum rates which may be charged for transportation has gone so far as to restrain the smooth working of basic economic laws. At this time of constantly increasing prices of raw materials and labor the limit of profit has become more or less fixed in the case of railroads, whereas the manufacturing companies are practically free to increase the prices of their products commensurate with the advance in their operating costs. From the investor's standpoint these conditions have produced a clear distinction between the railroads and industrials. For with the former it is becoming now largely a question of maintaining their earning power by making new capital expenditures, while with the latter new capital is almost always productive of an increase in earning power.

(674) 
The necessity of changing the motive power of railroads from steam to electricity, of driving tunnels under rivers, of vast enlargements of terminal facilities, such as we have seen in the case of the New York Central and the Pennsylvania Railroads, requires an outlay of capital on which the return is certain to be small, at least in comparison with the results of former years.

One of the most vital influences on both railroads and industrials lies in the development of legislation affecting them. While up to the present we have not progressed far enough to determine the final outcome, it would seem that industrial corporations have less to fear from this source than the railroads, for the reason that transportation companies are quasi-public institutions, while manufacturing companies are entirely private in their character. A public service or an interstate commerce commission may arbitrarily order an increase in the number of trains run, or reduce the rates which may be charged, but no law except that of demand and supply regulates the output of the factory or the price of its products. Carried to an extreme, present railroad legislation would result in government ownership of the railroads. Indeed, we have only to glance at Europe to see the very achievement of this. It seems less likely, however, that, in the words of a socialistic journal, we are about to "let the nation own the trusts," or any other form of private manufacturing enterprise. In most foreign countries to-day the shares of the industrial companies offer exclusively the most attractive opportunities for general investment.

Allusion has been made above to the present as the manufacturing age in this country. Without doubt one of the greatest causes in making it so has been the combination of capital. The stability of industrial stocks as investments rests on their power to earn fair profits under all circumstances. In other words, they must be independent, in so far as possible, of local influences, either in a special line of trade or in one particular country. Through the combination of smaller units into the great industrial corporations of to-day, these problems have been solved in a highly satisfactory manner; in the first instance by diversifying their products, as, for example, the United States Steel Corporation, which manufactures everything from steel rails to wire nails; the International Harvester Company, which produces twine as well as the most complicated harvesting machinery; the American Locomotive Company, which builds auto- 
mobiles and locomotives, and so forth. By establishing selling agencies and building up a clientele in foreign countries, and in some instances by actually installing manufacturing plants abroad, the industrial companies have largely insured themselves and their shareholders against dangers from purely local causes arising in any single country.

The large industrial companies are responsible for the great progress in the scientific methods of manufacture. In practically every case they maintain a large experimental department with a staff of highly trained experts. By this means chiefly has it been possible to discover the most economic methods of manufacturing and to achieve remarkable results in the utilization of by-products, which heretofore had been counted as total waste. The enormous expense of this experimentation, which necessarily often yields nothing, naturally prohibits the small manufacturer from engaging in it, although he frequently profits by the results.

The control of the supply of raw materials has injected still another great element of strength into the industrial companies. A very large number of manufacturing companies control their own coal, iron, copper or tin mines, limestone quarries or forests of timber, or whatever they may require in the manufacture of their finished product. The value of this lies not only in the protection against extreme price fluctuations, but also in the certainty of obtaining a constant and sufficient supply at all times and under all circumstances. In many cases this policy extends not only to the control or ownership of raw materials, but also to adjunct manufactures and transportation facilities, either on land or by water.

Recent developments in the United States have been such as to make industrial shares more desirable to the investor than ever. In the panic of 1907 , and in the business depression which followed it, the financial soundness and earning power of all business enterprises were put to a very severe test, and the record of only one important receivership among industrial companies, which was due primarily to injudicious financing rather than to the falling off of the company's own earning power, is most significant, especially when contrasted with the record of the railroads showing twenty-four receiverships involving over 8,000 miles of road. Furthermore, many large industrial companies have in the very recent years made additions and extensions, in many cases out of earnings, to the capacities 
of their plants, with the general result that they are in a position to handle more business at a greater profit than formerly.

Most of the stocks of the larger industrial companies are listed on the New York Stock Exchange. Not only does this give them the important advantage of a free and broad market, which makes them acceptable collateral in loans, but it also enforces the fullest publicity as to earnings and operations, which is seldom found to exist among companies not listed on the exchange. It is gratifying to note that the tendency of the stock exchange is to require more and more complete reports. The relatively higher standing in the eyes of investors which is enjoyed by the companies giving the most complete information, is gradually causing all the large companies voluntarily to take the public into their confidence to the fullest extent possible. This is even more important in the case of foreigners, who have fewer facilities than domestic investors for obtaining reliable information on companies in which they are interested, unless such information is given in an official statement of the company.

The question of the relation of the tariff to industrial companies has too many ramifications to be discussed here at length. Suffice it to say that one of the most important reasons for the establishment of the tariff was to protect and promote the growth of our infant industries. Most of these have by now become firmly entrenched. Due to their natural growth and the growth of the country, their perfect organizations and scientific methods, they are now in a position to conduct operations at a substantial profit, and even if part of the protection were removed they could still compete successfully with foreign products. Past experience has shown us, however, that such changes come about gradually, allowing plenty of time for the adjustment to take place.

In general it may be said that the preferred shares of industrial corporations represent the immediate earning power at the time of organization, and that the common stocks represent the hopes and possibilities of the future-which in most cases of industrial companies have been more than realized. Recently, though, there has been a healthy tendency to issue common stocks, based conservatively on an actual earning power, the International Harvester Company being a notable case in point. Naturally, from the standpoint of pure investment, without regard to speculative possibilities, the preferred stocks are more desirable than the common, but there are 
special cases where the preferred has also a speculative value, as, for example, those which share in dividends with the common after a certain amount has been paid on the latter, or in other cases where a newly issued security has not yet had an appreciation in value which steady absorption by investors generally produces.

The following table gives a list of twenty companies, whose shares are quoted on the New York Stock Exchange. These companies, which are representative of the general class of industrial corporations, both in respect to their financial standing and the character of their products, show a record of having paid the dividends on their preferred stocks without interruption, with the exception of one company, whose dividend in arrears amounts to a little more than one semi-annual payment. The average rate paid by these companies is 6.65 per cent. This average dividend was earned on an average two and five-eighths times over. The average price of the preferred shares of these companies was IO7 on March Ist, making the average yield 6.I9 per cent. These figures seem to give pointed evidence as to the safety and attractiveness of industrial stocks as investments:

\begin{tabular}{|c|c|c|}
\hline & $\begin{array}{l}\text { Incorpo- } \\
\text { porated } \\
\text { in }\end{array}$ & $\begin{array}{c}\text { First } \\
\text { Dividend } \\
\text { Paid in }\end{array}$ \\
\hline can Agricultural Ch & & \\
\hline erican Beet Sugar, 6 per cent. non-cumulative. & 1899 & 1899 \\
\hline nerican Car and Foundry, 7 per cent. non-cumulative.. & 1899 & I 899 \\
\hline erican Cotton Oil, 6 per cent. non-cumulative....... & 1889 & 1892 \\
\hline American Locomotive, 7 per cent. cumulative...... & $190 \mathrm{I}$ & IgOI \\
\hline American Smelting and Refining, 7 per cent. cumulative & I 899 & 1899 \\
\hline American Sugar Refining, 7 per cent. cumulative.. & $189 \mathrm{r}$ & $189 \mathrm{I}$ \\
\hline American Tobacco, 6 per cent. cumulative. & 1904 & 1905 \\
\hline American Woolen, 7 per cent. cumulative.. & 1899 & 1899 \\
\hline Du Pont de Nemours, 5 per cent. cumulative. & 1903 & 1903 \\
\hline General Chemical, 6 per cent. cumulative... & 1899 & 1899 \\
\hline International Harvester, 7 per cent. cumulative. & 1902 & $1907^{1}$ \\
\hline International Steam Pump, 6 per cent. cumulativ & I 899 & 1899 \\
\hline National Biscuit, 7 per cent. cumulative.. & 1898 & 1898 \\
\hline National Lead, 7 per cent. cumulative........... & $\mathrm{I} 89 \mathrm{I}$ & 1892 \\
\hline Pressed Steel Car, 7 per cent. non-cumulative........... & 1899 & 1899 \\
\hline Railway Steel Spring, 7 per cent. cumulative.... & 1902 & 1902 \\
\hline epublic Iron and Steel, 7 per cent. cumulative.. & 1899 & 1890 \\
\hline United States Steel, 7 per cent. cumulative..... & I9OI & 1901 \\
\hline ginia-Carolina Chemical, 8 per cent. cumula & 1895 & 1895 \\
\hline
\end{tabular}

Preferred stock issued in 1907. 